\title{
NEWKEY-BURDEN, Chas. The Wanted: a biografia não au- torizada. Tradução de Mariana Varella. São Paulo: Prumo, 2013. 200p.
}

José Helder de Lima Costa* Universidade Federal do Ceará

Chas Newkey-Burden, cujo nome de batismo é Charles Philip Newkey-Burden, nascido em 1973, é jornalista e escritor britânico, autor de biografias de celebridades internacionais da música e do entretenimento, como Simon Cowell, Michael Jackson, Amy Whinehouse e Justin Bierber. Chas escreveu mais de 28 livros, e parte de suas obras foram traduzidas para mais de treze idiomas.

Nesta obra, o autor escreve a biografia de um grupo de jovens do Reino Unido que se reuniu em 2009 para formar uma banda juvenil de pop rock, comumente rotulada de boy band, a The Wanted.

Muito embora a biografia seja um gênero de narrativa não-ficcional ${ }^{1}$, esta geralmente expõe os fatos em ordem cronológica, "The Wanted, A Biografia Não-Autorizada" inicia, após um breve prólogo, os seus cinco primeiros capítulos, narrando fatos marcantes da infância e do convívio familiar de cada um dos cinco componentes da boy band: Max George, Tom Parker, Siva Kaneswaran,

\footnotetext{
* Mestrando no Programa de Pós-graduação em Estudos da Tradução, na Universidade Federal do Ceará. Fortaleza, Ceará, Brasil. E-mail: tradutor062@gmail.com

${ }^{1}$ Pesquisado em: http://educacao.uol.com.br. Acessado em 05/06/2016.
} 
Jay MacGuines e Nathan James Sykes, respectivamente. Há um destaque para a primeira página de cada capítulo, na qual o autor apresenta uma ficha com as seguintes informações: "Nome Completo"; "Local de Nascimento"; "Data de Nascimento"; "Signo"; "Altura"; "Cor dos Olhos"; "Cor dos Cabelos"; "Prato Predileto"; "Banda Predileta"; "Time de Futebol"; "Animal Predileto" e "Programa de TV Favorito".

Nos capítulos seguintes, o autor narra fatos marcantes que precederam a formação da The Wanted, destinando um espaço generoso a um dos componentes, Max George, para o qual foi dedicado um capítulo à parte: "The Max Factor" 2 , que conta a trajetória artística de Max George, antes de se juntar à "The Wanted”. Ele é considerado, pelo biógrafo, a "voz da razão para os outros membros do grupo" (p. 16).

O autor narra, no capítulo seguinte, a cronologia histórica das boy bands, desde o seu primeiro registro, ainda nos anos de 1950, com o grupo "The Osmonds"; nos anos 1960, os irmãos Jacksons e "The Monkees", nos anos 1980 e 1990, os "New Kids On The Block" e a *NSYNC.

Nos capítulos 8 e 9, o autor passa a narrar os fatos envolvendo a "The Wanted" de forma cronológica, desde o nascimento da banda, que foi reunida durante um processo de audição artística promovido pela empresa "Maximum Artist Management", passando pelos acontecimentos que geraram uma carreira de ascensão meteórica, surgida com o primeiro single "All Time Low", seguido de outros sucessos como "Heart Vacancy" e "Glad You Came". Encerra a publicação o capítulo 10, dedicado aos planos futuros da banda, que incluía uma turnê pelos Estados Unidos. Na época em que a biografia estava sendo escrita, esta turnê já estava sendo

${ }^{2} \mathrm{O}$ autor faz um trocadilho com o nome do show de talentos britânico "X-Factor" no qual Max, em meio a acontecimentos controversos, concorreu no início de sua carreira artística.

Cad. Trad., Florianópolis, v. 37， no 3，p. 373-378, set-dez 2017 
articulada por meio de um trabalho promocional ocorrido em Los Angeles, em setembro de 2010.

A obra original analisada é a publicação eletrônica (ISBN: 978-184317-966-5 ePub format) de 2012, disponível na Amazon.com. Nela, o design é mais tímido do que a o escolhido pela editora brasileira. Na edição em inglês, há apenas uma espécie de mancha trincada na abertura de cada capítulo; na edição em português, cada capítulo se inicia com uma página escura com manchas de pegadas de sapatos, as quais acompanham boa parte da área de cada página da obra. Foram mantidas, porém, as seguintes marcas visuais da obra original: uma capitular no início de cada capítulo; o nome da banda "THE WANTED" em letras maiúsculas, seccionando partes do texto, assim como as mensagens dos componentes da banda veiculadas no Twitter ${ }^{\circledR}$ e o destaque de frases de efeito retiradas do texto. Estas duas últimas marcas visuais encontram-se bem mais destacadas no texto traduzido.

Agora, passamos a analisar algumas escolhas feitas pela tradutora, Mariana Varella, que nos chamaram a atenção por motivos diversos.

No capítulo 1, no início do segundo parágrafo, ao referir-se à coleção de objetos pessoais de Elton John, que no original foi descrita com o substantivo "memorabilia" a autora optou por uma expressão menos usual, "recordação pessoal” (p. 15).

Ao final deste primeiro capítulo, no antepenúltimo parágrafo, o texto original fora assim grafado: "Max showed his philosophical side [...]". A tradutora preferiu distanciar-se da escolha do autor e transpôs a frase acima da seguinte forma: "Max mostrou seu equilíbrio psicológico [...]" (p. 26).

O registro que o autor utilizou para descrever a bagunça criada quando os membros da banda decidiram ir morar juntos foi "for- 
midable", tendo visivelmente uma conotação negativa em inglês. No entanto, optou por um registro próximo à grafia do lexema original, utilizando o adjetivo "formidável” (p. 32), não reproduz o sentido original, visto que este adjetivo, em português, é largamente aplicado para qualificar pessoas, objetos ou ações de forma positiva.

Na página 34, segundo parágrafo, a tradutora traduziu o termo "primary school" para como "escola primária"; no entanto, quando, logo em seguida, o autor escreve o termo "secondary school" a tradutora optou "ensino médio", que é a nomenclatura oficial para esse nível de ensino. Nesse mesmo parágrafo, a tradutora traduziu literalmente o verbo original na seguinte frase: "My big brother encouraged me to pick up a guitar" como "Meu irmão mais velho me encorajou a tocar guitarra". No entanto, o equivalente mais usado em português seria "incentivou".

No quinto parágrafo do capítulo 3, o autor novamente lança mão do adjetivo "formidable", dessa vez com uma conotação positiva, para descrever a mãe de Siva, Elizabeth. Nesse caso, o termo parece adequado.

$\mathrm{Na}$ seguinte frase do penúltimo parágrafo deste capítulo: "Eu me apaixonei pela música e por cantar por causa de Hazel", vê-se que a escolha tradutória de "por cantar", embora tenha se refira a um jovem em um momento descontraído durante uma entrevista, deixou a frase um pouco confusa. O original "I fell in love with music and doing singing through Hazel" não possui uma construção gramatical próxima do português, razão pela qual uma tradução mais funcional seria algo como: "Me apaixonei pela música e pelo canto por influência da Hazel”.

Na oração traduzida: "Logo depois, Max e sua banda foram impulsionados quando foram convidados [...]" (p. 101); onde, no original, consta: "Soon after this, Max and his band got a major boost 
when they were invited [...]" vê-se que a utilização dos verbos compostos gerou uma repetição que poderia ter sido evitada pelo uso mais próximo do sentido original, por exemplo: "Logo depois disso, Max e sua banda ganharam uma enorme projeção ao serem convidados $[\ldots] "$.

No texto original, o último parágrafo do capítulo 8, a construção original "When they arrived at the MTV studios, they were confronted by the most excited fans to date" onde se utilizou a formação “were confronted by" parece estar deslocada de seu sentido original, já que no idioma inglês, da forma como está, costuma ter uma conotação negativa.

Nas páginas 144 e 145 encontramos dois registros de tradução e uma nota explicativa, todos entre colchetes, feitas por Varella: "Lincs FM Birthday Blash [Festa de Aniversário da Lincs FM]"; "SECC [Centro Escocês de Exibições e Conferências]" e "Summertime Ball [festival organizado pela Global Radio]; no entanto, isso não se repetiu em siglas como "BRIT Awards" (p. 85) "Metro" p. 95 e "HMV" (p. 145). Há também registros tradutórios anteriores em "Massive Millenium Showcase [Grande Exibição do Milênio]" (p. 72) e "Jack the Lad Swing [O balanço do jovem Jack]" (p. 117). Expressões coloquiais, como "pin-up" (p. 113) e "mash-up" (p. 153), por outro lado, permanecerem tal qual o original inglês.

Por se tratar de uma biografia voltada para um público jovem, que narra a trajetória de sucesso de cinco rapazes que compõem a boy band "The Wanted", a linguagem utilizada pelo autor apresentava o desafio da reprodução da coloquialidade, o que foi feito de maneira eficaz pela tradutora. 
De fato, o essencial do texto inglês foi transposto com êxito para o português. Em resumo, trata-se de um competente trabalho tradutório e editorial.

Recebido em: 01/04/2017 Aceito em: 11/06/2017 Publicado em setembro de 2017

3. The American Heritage Dictionay. Third Edition. Version 3.6 Copyright ${ }^{\circledR}$ 1994. SottKey International Inc., Recebido em: 01/12/2016 